\title{
The Conservation Efforts of Wood Apple, An Identity Plant of Rembang Regency, Based on Ethnobotany Study
}

\author{
${ }^{\square}$ Enni Suwarsi Rahayu, Nur Kusuma Dewi, Lina Herlina, Talitha Widiatningrum
}

DOI: 10.15294/biosaintifika.v9i3.11542

Department of Biology, Faculty of Mathematics and Natural Science, Universitas Negeri Semarang, Indonesia

\section{History Article}

Received 18 August 2017 Approved 17 November 2017 Published 31 December 2017

\section{Keywords}

Ethnobotany; Rembang; Traditional knowledge; Wood apple

\begin{abstract}
Feronia limonia (L.) Swingle better known as wood apple is an identity plant of Rembang Regency, Central Java Province, Indonesia. However, the population is very limited. In order to identify the conservation efforts, this ethnobotany study was aimed to determine traditional knowledge on the existence, economic value, utility, breeding technique and conservation of wood apple. The survey was conducted on a total of 102 local people from 10 sub-districts which were determined by proportionally stratified random sampling. Data were collected by questionnaires and individual interviews and then were analyzed descriptively. The results showed that all of respondents knew the figure of wood apple, but only $79.50 \%$ understood its status as an identity plant. Most of respondents (96\%) stated that the fruits have low economic value, $80.39 \%$ respondents have utilized ripe fruit as ingredients of beverages and stems as firewood. This utilization was only equal to $29.72 \%$ compared to the potential usability based on research results. It was concluded that the traditional knowledge about the existence, economic value, and breeding technique were good and on the contrary, the knowledge about the plant's usability was bad. The results will form a basic knowledge for in-depth studies to provide a government policy of Rembang Regency in order to develop an efficient strategy of management and conservation of wood apple as plant identity.
\end{abstract}

\section{How to Cite}

Rahayu, E. S., Dewi, N. K., Herlina, L., \& Widiatningrum, T. (2017). The Conservation Efforts of Wood Apple, An Identity Plant of Rembang Regency, Based on Ethnobotany Study. Biosaintifika: Journal of Biology \& Biology Education, 9(3), 474482 .

(C) 2017 Universitas Negeri Semarang
Correspondence Author:

D6 Building Floor 1 Sekaran, Gunungpati, Semarang, Indonesia 50229

E-mail: enni_sr@unnes.mail.ac.id
p-ISSN 2085-191X e-ISSN 2338-7610 


\section{INTRODUCTION}

All of regencies of Central of Java Province have established a species as an identity plant. It is aimed to provide the maximum effort to maintain the existence of the plant germplasm. The determining of identity plant is based on some factors, including historical value, endemicity, as well as intensity of cultivation. Rembang Regency chooses Feronia limonia (L.) Swingle which better known as wood apple as its identity plant. In Central Java Province, wood apple grows only in this regency. For the last 3 years, the population of wood apple is very limited, ranges from 498 - 1,042 trees (Statistics of Rembang Regency, 2016). The population of a species in a region is influenced by several factors, mainly the intensity of cultivation. The more intensive the cultivation will be resulted in a higher population. Intensity of cultivation of a species is influenced by several aspects of ethnobotany, especially the level of traditional knowledge of the community about the usefulness, the economic value, and the ease of breeding (Albuquerque, 2009).

To increase the population of wood apple in Rembang Regency, it is necessary to study the level of traditional knowledge about the three things mentioned above. It is necessary in order to maintain the traditional knowledge as well as to optimize sustainable use (Albuquerque $e t$ al., 2009). Recently, study of traditional knowledge often focuses on the role of demographic factors, such as age, gender, educational level, profession, and live duration in an area because these factors can form traditional knowledge (Ayantunde et al., 2008, Cruz et al., 2013).

Ethnobotany researches have been conducted on a group of plants such as all of plants species used in an area (Luizza et al., 2013), and medicinal plants (Kewessa et al. 2015). The ethnobotany researches also have been carried out on a plant species, such as cassava (Ellen \& Soselisa, 2012), sanseviera (Takawira - Nyenya et al., 2014), rattan, and bamboo (Honfo et al., 2015). During this time, the ethnobotany study on the identity plant of regency in Indonesia has never been published.

The study was aimed to describe the traditional knowledge of local people in Rembang Regency, specially about: 1) the existence and status, 2 ) the economic value and utilization, 3) the types of organs utilized, and 4) the breeding technique; and the perceptions of conservation of wood apple. The result was useful to provide a basis of government policy of Rembang Regency in order to develop an efficient strategy of management and conservation of wood apple as plant identity.

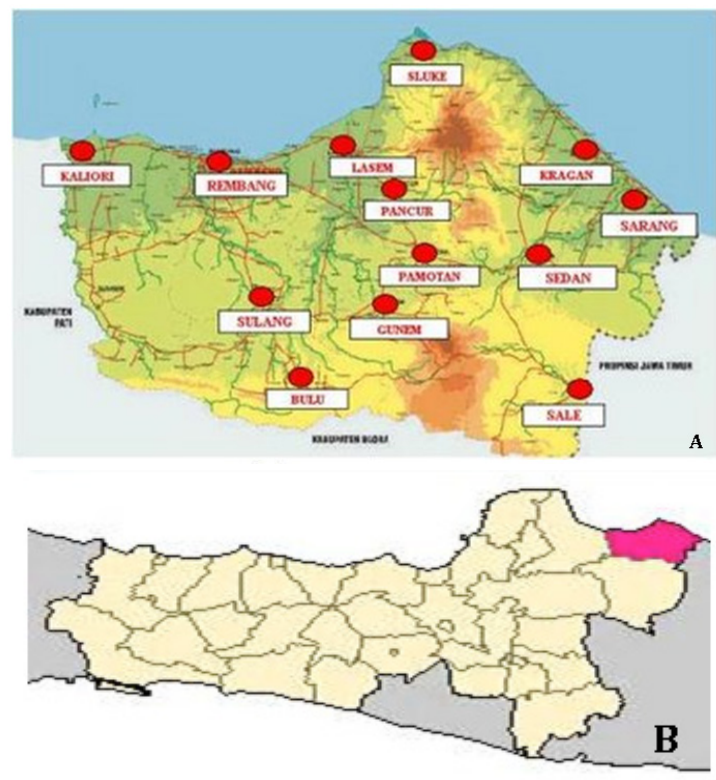

Figure 1. Rembang Regency. A. The 14 subdistricts of Rembang. B. Location of Rembang Regency is on the north coast of Java Island, in the border between the Central of Java and East of Java.

\section{METHODS}

The study was carried out in Rembang Regency in August to October 2017. The regency covers an area of 101,408 ha. Most of the area $(46.39 \%)$ is lowland in the northern part $(0-25 \mathrm{~m}$ above sea level), while in the south it is relatively higher between 100-500 $\mathrm{m}$ above sea level. It has a tropical climate type, with an average of rainfall is $502.36 \mathrm{~mm} /$ year, and daily temperature ranged from $23^{\circ} \mathrm{C}$ to $33^{\circ} \mathrm{C}$. The soil type is about $45 \%$ Mediterranean soil, 32\% grumusol, 10\% alluvial, and the rest are andosol and regosol. The area encompasses 14 sub-districts (Figure 1), of which 13 of them are rural and another one is urban. The population is estimated to reach 621,134 with a density between 259 - 1.519 inhabitants per $\mathrm{km}^{2}$. The population consists of 309,564 men and 311,570 women. Farming is the main occupation $(44.70 \%$ ) (Statistics of Rembang Regency, 2016).

An ethnobotanical survey was conducted in 10 sub-districts selected by purposive sampling. The samples consist of 5 sub-districts located on the coast and 5 sub-districts in the inland. From each sub-district, as many as 102 respondents were selected by stratified proportional random technique depend on their gender and age (Table 
Table 1. Gender and age proportion of sample

\begin{tabular}{|c|c|c|c|c|c|c|c|c|}
\hline \multirow{2}{*}{$\begin{array}{l}\text { Sub- } \\
\text { district }\end{array}$} & \multirow[b]{2}{*}{ Location } & \multicolumn{3}{|c|}{ Men } & \multicolumn{3}{|c|}{ Women } & \multirow{2}{*}{$\begin{array}{c}\text { Total } \\
\text { number }\end{array}$} \\
\hline & & $\begin{array}{c}\text { Youth } \\
<30\end{array}$ & $\begin{array}{c}\text { Adult } \\
30-55\end{array}$ & $\begin{array}{c}\text { Old } \\
>55 \\
\end{array}$ & $\begin{array}{c}\text { Youth } \\
<30\end{array}$ & $\begin{array}{c}\text { Adult } \\
30-55\end{array}$ & $\begin{array}{c}\text { Old } \\
>55 \\
\end{array}$ & \\
\hline Bulu & Coast & 2 & 3 & 1 & 1 & 3 & 1 & 11 \\
\hline Pamotan & Coast & 3 & 2 & 2 & 1 & 2 & 2 & 12 \\
\hline Gunem & Coast & 1 & 3 & 1 & 3 & 2 & 1 & 11 \\
\hline Pancur & Coast & 1 & 4 & 0 & 2 & 4 & 0 & 11 \\
\hline Sulang & Coast & 2 & 2 & 1 & 2 & 3 & 0 & 10 \\
\hline Sluke & Inland & 0 & 2 & 2 & 2 & 4 & 2 & 12 \\
\hline Sarang & Inland & 2 & 1 & 1 & 3 & 3 & 1 & 11 \\
\hline Rembang & Inland & 1 & 3 & 1 & 1 & 3 & 1 & 10 \\
\hline Kaliori & Inland & 2 & 1 & 0 & 2 & 1 & 1 & 7 \\
\hline Lasem & Inland & 2 & 2 & 1 & 1 & 1 & 0 & 7 \\
\hline \multicolumn{2}{|l|}{ Sub-total } & 16 & 23 & 10 & 18 & 26 & 9 & \multirow{2}{*}{102} \\
\hline \multicolumn{2}{|c|}{ Total number } & & 49 & & & 53 & & \\
\hline
\end{tabular}

1). It is stated that a minimum number required for a qualitative interview study to be published can be between 20 to 30 persons.

The focuses of this research were the traditional knowledge about 1) the existence and status, 2) the economic value and utilization, 3 ) the types of organs utilized, and 4) breeding technique; and the community perceptions about conservation of wood apple. Data were collected by questionnaire, interview, and observation methods. Questionnaires and interviews was individually conducted used a semi-structured questionnaire.

Traditional knowledge of the respondents on wood apple was measured using the Reported Use Value (RUV) i.e. the total number of plants uses reported by respondents. The RUV then was compared to the Theoretical Use Value (TUV) to determine the increase of efforts required. To identify the most used wood apple part, Organ Use Value (OUV) was calculated. OUV was defined as the ratio of the total number of an organ utilization $\left(\mathrm{RU}_{\mathrm{org}}\right)$ to the total number of reported utilization $\left(\mathrm{RU}_{\text {total }}\right)$ for the all of organs (GomezBeloz, 2002).

$\mathrm{OUV}=\left(\mathrm{RU}_{\text {org }} \times 100\right) / \mathrm{RU}_{\text {total }}$

\section{RESULTS AND DISCUSSION}

The respondents have various educational levels and occupations; under/post graduate and government employees were the least compared to the others. Most respondents have lived in Rembang for more than 5 years (Table 2).
Interview and questionnaire results revealed that all of respondents were familiar with wood apple figure, but only $79.50 \%$ of them understood its status as an identity plant of Rembang Regency (Table 3). Most of the respondents noticed the trees grow in the yard (Figure $3 \mathrm{~A}$ ) and roadside, and $5.88 \%$ of them confirmed some wood apple trees grew at plantation in Rembang. However, the observations in this study did not find the plantation. More than half of the respondents told that so far they found less than 5 wood apple trees (Table 3). It proved that the existence of wood apple is really limited.

Wood apple was known to have economic value, especially its fruit. However, according to more than half of respondents, the economic value was relatively low. All respondents understood the benefits of wood apple. Most of them had ever consumed the fruit, generally 1-3 times per month (Table 4) because they did not like the taste or they felt hard to found the fruit at a certain time. Most respondents used wood apple as food/beverage and firewood. A small proportion of them used it as building construction materials, medicine, animal feed, reforestation and ornamental plants (Figure 2).

The wood apple organs used were stems for house construction, young leaves for fodder (Fig 3B), ripe fruit (Figure 3C, 3D) for drinks, and whole plants as ornamental plants and reforestation. These utilizations were still very limited compared to benefits based on research results for each organ. Based on some researches in many regions and countries; the root, unripe fruit and 
Table 2. Distribution of research samples based on educational level, occupation and live duration in Rembang

\begin{tabular}{|c|c|c|c|c|c|c|c|c|c|c|c|c|}
\hline \multirow[t]{2}{*}{$\begin{array}{l}\text { Sub } \\
\text { district }\end{array}$} & \multicolumn{4}{|c|}{$\begin{array}{c}\text { Educational } \\
\text { level* }\end{array}$} & \multicolumn{5}{|c|}{ Occupation** } & \multicolumn{2}{|c|}{$\begin{array}{c}\text { Live } \\
\text { duration } \\
\text { in Rem- } \\
\text { bang }\end{array}$} & \multirow[t]{2}{*}{$\begin{array}{l}\text { Total } \\
\text { num- } \\
\text { ber }\end{array}$} \\
\hline & A & $\mathrm{B}$ & C & $\mathrm{D}$ & A & B & C & $\mathrm{D}$ & E & $<5$ & $>5$ & \\
\hline Bulu & 3 & 2 & 3 & 3 & 1 & 6 & 1 & 0 & 3 & 3 & 8 & 11 \\
\hline Pamotan & 3 & 4 & 3 & 2 & 1 & 3 & 4 & 2 & 2 & 6 & 6 & 12 \\
\hline Gunem & 3 & 3 & 5 & 0 & 0 & 5 & 2 & 1 & 3 & 7 & 4 & 11 \\
\hline Pancur & 4 & 1 & 6 & 0 & 0 & 4 & 3 & 1 & 2 & 5 & 6 & 11 \\
\hline Sulang & 2 & 2 & 5 & 1 & 0 & 4 & 3 & 2 & 0 & 1 & 9 & 10 \\
\hline Sluke & 5 & 3 & 2 & 2 & 2 & 3 & 2 & 2 & 1 & 0 & 12 & 12 \\
\hline Sarang & 7 & 3 & 1 & 0 & 3 & 1 & 1 & 0 & 6 & 0 & 11 & 11 \\
\hline Rembang & 4 & 1 & 2 & 3 & 1 & 4 & 3 & 1 & 3 & 2 & 8 & 10 \\
\hline Kaliori & 2 & 3 & 2 & 0 & 1 & 4 & 0 & 1 & 3 & 1 & 6 & 7 \\
\hline Lasem & 3 & 3 & 1 & 0 & 1 & 3 & 0 & 1 & 2 & 4 & 3 & 7 \\
\hline Total & 36 & 25 & 30 & 11 & 10 & 37 & 19 & 11 & 25 & 29 & 73 & 102 \\
\hline
\end{tabular}

* A: elementary school; B: yunior high school; C: senior high school; D: under/post graduate; ** A: government employees; B: private employees; C: farmer; D: trader: E: others

Table 3. Community knowledge about the existence of wood apple

\begin{tabular}{llll}
\hline Knowledge aspects & $\begin{array}{l}\text { Respondent } \\
\text { number }\end{array}$ & Percentage & Explanation \\
\hline The wood apple figure & & & \\
Yes & 102 & 100.00 & \\
No & 0 & 0.00 & \\
The status as identity plants & & & \\
Yes & 81 & 79.50 & \\
No & 21 & 20.50 & \\
The location of planting & & & \\
The yard & 63 & 61.76 & There are some respondents who know \\
Road side & 46 & 45.09 & that wood apple grows in two or more \\
Plantation & 6 & 5.88 & places \\
Number of plants ever seen & & & \\
$<5$ trees & 54 & 52.94 & \\
$5-10$ trees & 24 & 23.52 & \\
$11-20$ trees & 10 & 9.80 & \\
$21-30$ trees & 2 & 1.96 & \\
$>30$ trees & 12 & 11.76 & \\
\hline
\end{tabular}

bark actually have some potencies to be used for various purposes (Pradhan et al., 2012; Patel \& Pandey, 2014; Buvanaratchagan \& Dhandapani, 2016; Banupriya \& Vijayakumar, 2016), but the people of Rembang Regency did not use them at all. The stem, ripe fruit, and young leaf have also many utilities that have not been widely exploited by people of Rembang. It was calculated that there was $70.28 \%$ mean of ER or untapped potency; or in other words as much as only $29,72 \%$ of potency that had been used. Among the organs used, the fruit had $50 \%$ of OUV; it was the greatest and the most widely used by the community (Table 5). 
Enni Suwarsi Rahayu et al. / Biosaintifika 9 (3) (2017) 474-482

Table 4. Aspects of community knowledge of economic value and utilization of wood apple

\begin{tabular}{lcc}
\hline Knowledge aspects & Number & Percentage \\
\hline The economical value & & \\
Know & 98 & 96.07 \\
Do not know & 4 & 3.93 \\
The organs sold & & \\
Fruit & 95 & 93.14 \\
Stem & 3 & 2.94 \\
Do not know & 4 & 3.92 \\
The relative selling point & & \\
High & 17 & 16.67 \\
Medium & 11 & 10.78 \\
Low & 60 & 58.83 \\
Do not know & 4 & 3.92 \\
The benefits & & \\
Know & 102 & 100.00 \\
Do not know & 0 & 0 \\
Experience in utilize & & \\
Yes & 82 & 80.39 \\
No & 20 & 19.61 \\
Frequency of utilize & & \\
never use & 20 & 19.61 \\
1 - 3 times per month & 65 & 63.72 \\
4 - 6 times per month & 4 & 3.92 \\
7 - 9 times per month & 4 & 3.92 \\
10 - 12 times per month & 6 & 5.89 \\
More than 12 times per month & 3 & 2.94 \\
\hline
\end{tabular}

The majority of respondents $(74.51 \%)$ aware some techniques of wood apple reproduction, such as seed germinating, stem cutting and grafting (Table 6). Consequently, there are no plantations of wood apple from seedlings raised in nurseries. Moreover, about of half of respondents have never tried to plant wood apple. They commented that wood apple is a demanding species, and its seed germination and growth is very slow.

The low population of wood apple was responded by most respondents that this species needs to be preserved. According to them, the most important conservation effort was increasing the plantation and giving information about the various uses. In addition, it should also be done by making regulations, counseling, banning logging, and land preparation. On the contrary, a small percentage of respondents stated that the wood apple did not need to be conserved because of cheap price, less benefit, little usefulness, and low growth; and frequently the falling fruits cause roof damage (Table 6).

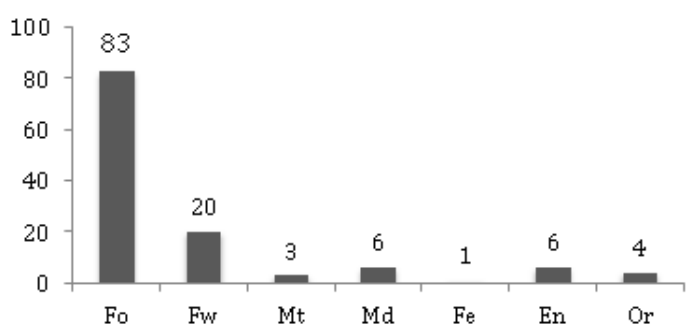

Figure 2. Number of respondents who mentioned types of wood apple usage. Fo: food; Fw: firewood; Mt: materials; Md: medicine; Fe: feed; En: environment/reforestation; Or: ornamental plant

The results above indicated that the main cause of the low wood apple population in Rem- 
Table 5. The use of wood apple organs and effort increase needed of the usage

\begin{tabular}{|c|c|c|c|c|c|}
\hline Organ & Factual usage & $\begin{array}{l}\text { Number of } \\
\text { factual usage }\end{array}$ & Theoretical usage* & $\begin{array}{l}\text { Number of } \\
\text { theoretical } \\
\text { usage }\end{array}$ & $\begin{array}{l}\text { Efforts in- } \\
\text { crease needed } \\
(\%)\end{array}$ \\
\hline Root & - & 0 & used against snakebite & 1 & 100 \\
\hline Stem & Construction & 1 & $\begin{array}{l}\text { Fuel } \\
\text { adulterant of gum } \\
\text { artists' watercolors, } \\
\text { ink, dyes and varnish } \\
\text { agricultural implements } \\
\text { Construction }\end{array}$ & 6 & 84 \\
\hline $\begin{array}{l}\text { Young } \\
\text { leaf }\end{array}$ & Fodder & 1 & $\begin{array}{l}\text { Fodder } \\
\text { intestinal troubles of } \\
\text { children } \\
\text { dysentery and diarrhea in } \\
\text { children } \\
\text { used against snakebite }\end{array}$ & 4 & 75 \\
\hline Ripe fruit & $\begin{array}{l}\text { eaten raw } \\
\text { drunk as a } \\
\text { beverage } \\
\text { making syrup } \\
\text { medicine }\end{array}$ & 4 & $\begin{array}{l}\text { eaten raw } \\
\text { drunk as a beverage } \\
\text { frozen as an ice cream } \\
\text { making jelly and jam } \\
\text { poulticed onto bites } \\
\text { and stings of venomous } \\
\text { insects }\end{array}$ & 6 & 33 \\
\hline $\begin{array}{l}\text { Unripe } \\
\text { fruit }\end{array}$ & - & 0 & $\begin{array}{l}\text { liver and cardiac tonic } \\
\text { treatment for hiccough, } \\
\text { sore throat }\end{array}$ & 2 & 100 \\
\hline Bark & - & 0 & $\begin{array}{l}\text { used against snakebite } \\
\text { applied on venomous } \\
\text { wounds. }\end{array}$ & 2 & 50 \\
\hline $\begin{array}{l}\text { Whole } \\
\text { plant }\end{array}$ & $\begin{array}{l}\text { Ornamental } \\
\text { Green plant }\end{array}$ & 2 & $\begin{array}{l}\text { roadside tree } \\
\text { Boundary or barrier }\end{array}$ & 2 & 0 \\
\hline
\end{tabular}

* Pradhan et al. (2012), Patel \& Pandey (2014), Buvanaratchagan \& Dhandapani (2016); Banupriya \& Vijayakumar (2016)

bang Regency was not due to the incompatibility of environmental factors for wood apple growth. Wood apple was found in almost all of the observed sub-districts, although the density varied. According to Orwa (2009), this species comes from India and its surroundings. Its origin area is dry and it can grow well at altitudes of up to $450 \mathrm{~m}$ with mean annual rainfall of $800-1,200$ $\mathrm{mm}$ and mean annual temperature of $20-29^{\circ} \mathrm{C}$ on various soil types. The Rembang region meets the needs of the microclimate because Rembang has a tropical climate type with an average of rainfall is $502.36 \mathrm{~mm} /$ year, and daily temperature ranged from $23^{\circ} \mathrm{C}$ to $33^{\circ} \mathrm{C}$. The Rembang region is mostly located on the beach (0-25 $\mathrm{m}$ above sea level) and inland (100-500 $\mathrm{m}$ above sea level) (Statistics of Rembang Regency, 2016).

The main cause of the low wood apple population was due to the anthropogenic activities, i.e. lack of understanding of the benefits 
Table 6. The frequency and value of use of wood apple organs

\begin{tabular}{|c|c|c|c|c|}
\hline Organs & $\begin{array}{l}\text { Respon- } \\
\text { dents } \\
\text { number }\end{array}$ & $\begin{array}{l}\text { Percent- } \\
\text { age (\%) }\end{array}$ & $\begin{array}{l}\text { Usage based on } \\
\text { respondent opinion }\end{array}$ & OUV \\
\hline Root & 0 & 0 & - & 0 \\
\hline Stem & 23 & 22.55 & Construction & 12.50 \\
\hline $\begin{array}{l}\text { Young } \\
\text { leaf }\end{array}$ & 1 & 0.09 & fodder & 12.50 \\
\hline Flower & 0 & 0 & - & 0 \\
\hline Fruit & 83 & 81.37 & $\begin{array}{l}\text { eaten raw } \\
\text { drunk as a beverage } \\
\text { making syrup } \\
\text { medicinal }\end{array}$ & 50.00 \\
\hline Bark & 6 & 5.88 & medicine & 12.50 \\
\hline $\begin{array}{l}\text { Whole } \\
\text { plant }\end{array}$ & 10 & 9.80 & $\begin{array}{l}\text { ornamental tree } \\
\text { reforestation }\end{array}$ & 25.00 \\
\hline
\end{tabular}

Table 7. Community knowledge on breeding technique and preservation of wood apple

\begin{tabular}{lcc}
\hline Aspects of knowledge & $\begin{array}{c}\text { Number of } \\
\text { respondents }\end{array}$ & Percentage \\
\hline Wood apple breeding & 76 & 74.51 \\
Understand & 26 & 25.49 \\
Do not understand & & \\
Known breeding technique & 70 & 68.62 \\
Seed & 9 & 8.82 \\
Cuttings & 1 & 0.98 \\
Grafting & 26 & 25.48 \\
Do not understand & & \\
Breeding experience & 52 & 50.98 \\
Have experience & 50 & 49.02 \\
Do not have experience & & \\
Perception of the preservation & 83 & 81.37 \\
Needed & 19 & 18.63 \\
Not needed & & \\
Preservation technique & 24 & 23.53 \\
increase usage & 44 & 43.14 \\
increase planting & 2 & 1.96 \\
making local regulations & 12 & 11.76 \\
create identity & 1 & 0.98 \\
others: counseling, provision of superior seeds, ban on logging, land & 19 & 18.63 \\
preparation & & \\
No needed & & \\
\hline
\end{tabular}

and attention to cultivation. The understanding of the benefits and cultivation of a plant species is a part of local knowledge. Traditional knowledge can be said as uniqueness in a community culture in the form of original knowledge, local knowledge and traditional values. Such knowledge covers agriculture, food supply, nature protection, and health. The inheritance system is done orally, using the expression of words in ceremonies, rituals, and customs (Cruz et al., 2013). The 

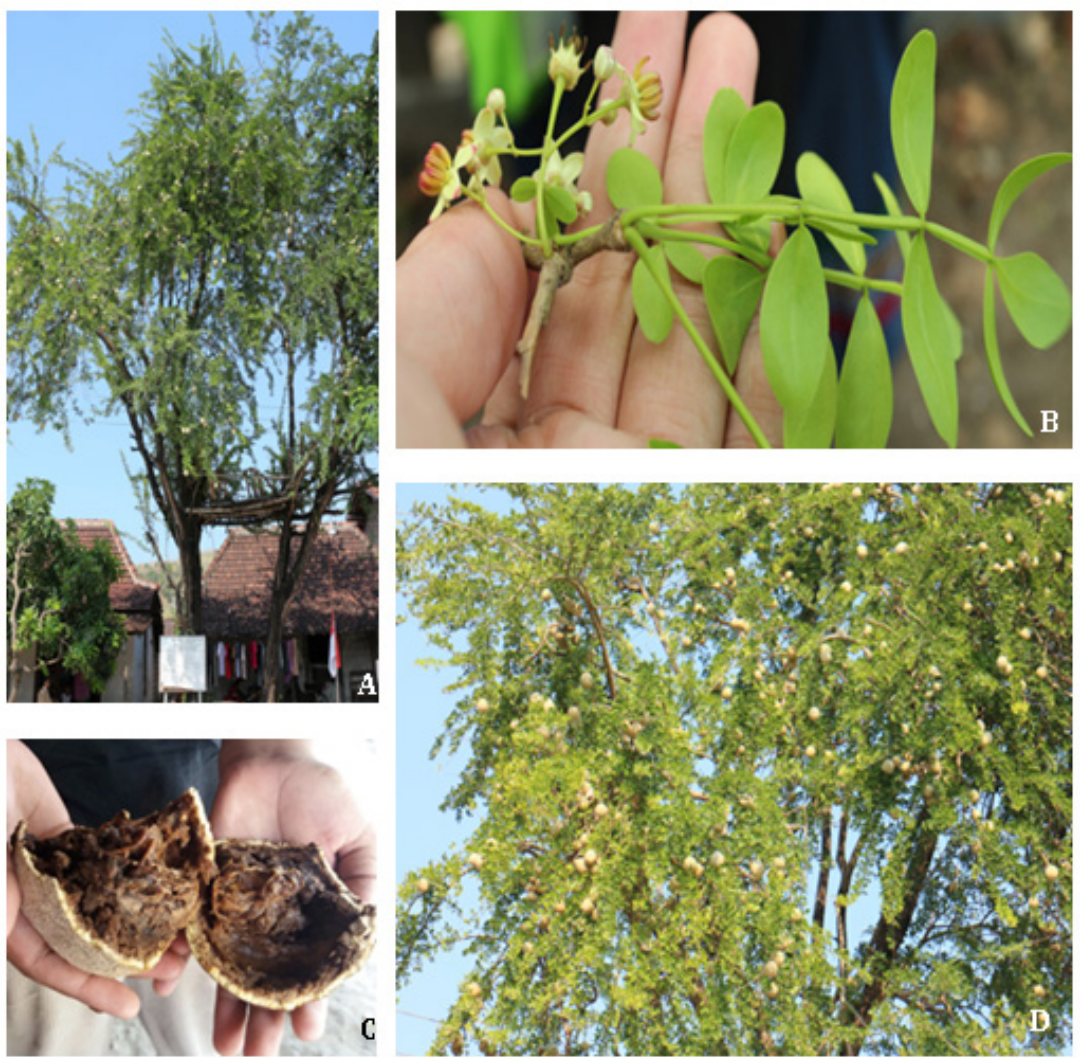

Figure 4. The morphology of wood apple. A. A tree grown at the yard at Sluke. B. The young leaves and flower. C. The pieces of ripe fruit shows brown fruit flesh. D. Fruits on the tree.

traditional knowledge of plants can be realized in the pattern of utilization of plants and traditional agriculture. Local people develop their traditional knowledge in a practical way in which they live. The phenomenon of traditional knowledge can be used as a conservation step (Luizza et al., 2013).

When designing sustainable strategies for management of species stands with implications for local people, the knowledge and use value of the people should be taken into consideration (Cruz et al. 2013). Accordingly, the people must be involved in the enhancement of the wood apple population. This involvement will be easier when the people understand the benefits of wood apple. The survey revealed that the majority of respondents understood the economic value of wood apple but the value was considered low. It was caused by the only use of the fruit, otherwise the other organs were almost never used. Consequently, it is necessary to educate community in order to disseminate the potential benefits.

Our results did not reveal a significant trade of wood apple product. This is due to the fact that the cultivation was not carried out on a large scale. Base on this finding, wood apple population should be increased through cultivation of the species in agroforestry systems and preserve on protected areas where they grow. This is the time for propagation of wood apple by planting through seeds germination in the nursery. Muna \& Rahayu (2015) suggested that new approaches should be explored, such as mycorrhiza application and compost in planting holes dug several months before planting. This practice has an advantage of creating a favorable microclimate, allowing the roots to survive during the dry season.

This study documented ethnobotanical local knowledge of wood apple. It is hoped that its results will form a basic knowledge for in-depth studies on this species. Future studies on the conservation should focus on the sustainability of utility methods. Biological studies need to be conducted on the medicinal use to generate information that wood apple could be used in future as drug development. The possibilities to improve plant quality through breeding are also need to be done.

\section{CONCLUSION}

The results showed that all of respondents knew the figure of wood apple, but only $79.50 \%$ of them understood its status as plant identity. 
Most of respondents (96\%) stated that the fruit has low economic value. There are $80.39 \%$ respondents that have utilized ripe fruit as ingredients of beverages and stems as firewood. This utilization was only equal to $29.72 \%$ compared to the potential usability based on the research results. The most important outcome was the finding that some respondents thought if conservation efforts should be undertaken, while the others stated that it is unnecessary due to falling fruit frequently cause roof damage and the plants' less economic profit. It was concluded that the traditional knowledge about the existence, economic value, and breeding technique were good; and on the contrary, the knowledge about the usability was bad.

Based on the results, it is suggested to educate local people about the importance of woody apple conservation, as well as to inform and train the various uses.

\section{REFERENCES}

Albuquerque, U. P., de Sousa Araújo, T. A., Ramos, M. A., Do Nascimento, V. T., de Lucena, R. F. P., Monteiro, J. M., Alencar, N. L. \& Lima Araújo, E. (2009). How ethnobotany can aid biodiversity conservations: Reflection on investigation in the semi-arid region of NE Brazil. Biodiversity and Conservation, 18(1), 127-150.

Ayantunde, A. A., Briejer, M., Hiernaux, P., Udo, H. M., \& Tabo, R. (2008). Botanical knowledge and its differentiation by age, gender and ethnicity in Southwestern Niger. Human Ecology, 36(6), 881-889.

Buvanaratchagan, A. \& Dhandapani, R. (2016). Antifungal Activity of Ethanolic Leaf Extract of $\mathrm{Li}$ monia acidissima against Dermatophytes. Scholars Journal of Applied Medical Sciences, 4(11D), 4161-4163

Banupriya, T. L. \& Vijayakumar, P. (2016). Anti nutrient and phytochemical screening of an underutilized fruit seed: Limonia acidissima. International Journal of Innovative Research In Technology, 2(9), 7-14

Begossi, A., Hanazaki, N., \& Tamashiro, J. Y. (2002). Medicinal plants in the Atlantic Forest (Brazil): knowledge, use, and conservation. Human ecology, 30(3), 281-299.

Cruz, M. P., Peroni, N., \& Albuquerque, U. P. (2013). Knowledge, use and management of native wild edible plants from a seasonal dry forest (NE, Brazil). Journal of Ethnobiology \& Ethno- medicine, 9(1), 79.

Ellen, R. F., \& Soselisa, H. L. (2012). A comparative study of the socio-ecological concomitants of cassava (Manihot esculenta Crantz) diversity, local knowledge and management in Eastern Indonesia. Ethnobotany Research and Applications, 10, 015-035.

Gomez-Beloz, A. (2002). Plant use knowledge of the Winikina Warao: the case for questionnaires in ethnobotany. Economic Botany, 56(3), 231-241.

Honfo, H., Tovissodé, F. C., Gnanglè, C., Mensah, S., Salako, V. K., Assogbadjo, A. E., Agbangla C., \& Kakaï, R. G. (2015). Traditional Knowledge and Use Value of Bamboo in Southeastern Benin: Implications for sustainable management. Ethnobotany Research and Applications, 14, 139-153.

Kewessa, G., Abebe, T., \& Demessie, A. (2015). Indigenous knowledge on the use and management of medicinal trees and shrubs in Dale District, Sidama Zone, Southern Ethiopia. Ethnobotany Research and Applications, 14, 171-182.

Luizza, M. W., Young, H., Kuroiwa, C., Evangelista, P., Worede, A., Bussmann, R., \& Weimer, A. (2013). Local Knowledge of Plants and their uses among Women in the Bale Mountains, Ethiopia. Ethnobotany Research \& Applications, 11, 315-339.

Muna, K., \& Rahayu, E. S. (2015). Optimasi Medium Pembibitan Kawista (Limonia acidissima L.) dengan Mikoriza Vesikular Arbuskular (MVA) dan Kompos. Life Science, 4(1), 22-28.

Orwa. (2009). Agroforestry Database 4.0. pp. 1-5.

Patel, A. S., \& Pandey, A. K. (2014). Fortification of Limonia acidissima Linn Fruit Powder to Develop the Phynolic Enriched Herbal Biscuits. Journal of Bioresource Engineering and Technology, 1, 74-85.

Pradhan, D., Tripathy, G., \& Patanaik, S. (2012). Anticancer activity of Limonia acidissima Linn (Rutaceae) fruit extracts on human breast cancer cell lines. Tropical Journal of Pharmaceutical Research, 11(3), 413-419.

Souto, T., \& Ticktin, T. (2012). Understanding Interrelationships Among Predictors (Age, Gender, and Origin) of Local Ecological Knowledge1. Economic Botany, 66(2), 149-164.

Statistics of Rembang Regency. (2016). Rembang in Figure. Rembang: Statistics of Rembang Regency.

Takawira-Nyenya, R., Newton, L. E., Wabuyele, E., \& Stedje, B. (2014). Ethnobotanical Uses of Sansevieria Thunb. (Asparagaceae) in Coast Province of Kenya. Ethnobotany Research \& Applications, 12, 051-069. 